Acta vet. scand. $1973,14,474-488$.

From the National Veterinary Institute and the Department of Bacteriology and Epizootology, Royal Veterinary College, Stockholm, Sweden.

\title{
SEROLOGICAL CROSS-REACTIONS BETWEEN DIFFERENT BRUCELLA SPECIES AND YERSINIA ENTEROCOLITICA
} AGGLUTINATING ACTIVITY OF $19 \mathrm{~S}$ AND $7 \mathrm{~S}$ ANTIBODIES
AGAINST SOMATIC ANTIGEN OF BRUCELLA ABORTUS
AND YERSINIA ENTEROCOLITICA TYPE IX

By

B. Hurvell

HURVELL, B.: Serological cross-reactions between different Brucella species and Yersinia enterocolitica. Agglutinating activity of $19 \mathrm{~S}$ and $7 S$ antibodies against somatic antigen of Brucella abortus and Yersinia enterocolitica type IX. Acta vet. scand. 1973, 14, 474-488. Antisera from rabbits immunized with acetone-killed whole cells and with lipopolysaccharides from Brucella abortus (B.a.) and Yersinia enterocolitica type IX (Y.e.) were gel-filtered on Sephadex G-200 columns.

All the antisera had serologically cross-reacting agglutinins against B.a. and Y.e. both in the $19 \mathrm{~S}$ and in the $7 \mathrm{~S}$ antibody fractions.

The homologous and the heterologous agglutinating activity of $19 \mathrm{~S}$ and of $7 \mathrm{~S}$ antibodies was tested before and after treatment with dithiothreitol (DTT) and subsequent alkylation. Unlike $19 \mathrm{~S}$ antibodies, $7 \mathrm{~S}$ antibodies were resistant to the D'TT reduction.

The results from heterologous absorptions of the respective $19 \mathrm{~S}$ and $7 \mathrm{~S}$ antibody fractions indicated that $19 \mathrm{~S}$ antibodies both to B.a. and to Y.e. had a greater tendency towards being absorbed to the crossreacting antigenic determinants than had the corresponding $7 \mathrm{~S}$ antibodies. The agglutination titres for 19 as well as $7 \mathrm{~S}$ antibody fractions derived from the immunizations with B.a. (both whole cells and LPS) fell more markedly after heterologous absorptions than did the analogous titres for corresponding Y.e. antibody fractions. Possible explanations of these differences are discussed.

serological cross-reactions; Brucella abortus; Yersinia enterocolitica serotype IX; $19 \mathrm{~S}$ antibodies; $7 \mathrm{~S}$ antibodies; agglutination.

In previous investigations concerning the serological crossreactions between different Brucella species and Yersinia entero- 
colitica type IX attempts have been made to characterize the cross-reacting antigenic determinants (Diaz et al. 1970, Hurvell 1972, 1973, Hurvell \& Lindberg 1973). Different serological methods have been used to show these cross-reactions (Ahvonen et al. 1969, Corbel \& Cullen 1970, Diaz et al. 1970, Hurvell et al. 1970, Akkermans \& Hill 1971, Fribourg-Blanc 1971, Szita et al. 1971, Wauters et al. 1971, Hurvell 1972, 1973, Hurvell \& Lindberg 1973), but no examinations and characterizations of separated cross-reacting antibodies to Brucella and Yersinia enterocolitica type IX have been performed.

The object of the present investigation was to compare the cross-agglutinating activity of $19 \mathrm{~S}$ and $7 \mathrm{~S}$ antibodies against somatic antigens of Brucella abortus and Yersinia enterocolitica type IX. By the methods of Sephadex G-200 column chromatography the $19 \mathrm{~S}$ and $7 \mathrm{~S}$ antibodies were fractionated and the influence on their agglutinating activity by thiol-reducing agent and crosswise absorptions was tested.

\section{MATERIAL AND METHODS \\ Preparation of lipopolysaccharides}

B. abortus (B.a.) and Y. enterocolitica type IX (Y.e.) lipopolysaccharides (LPS) recovered from the phenol phase (F 5) at the hot phenol-water extraction have been described previously (Hurvell 1973).

Antisera

Preimmunization sera of rabbits (SPF-rabbits, FFV, Åkers Styckebruk, Sweden) were checked for their content of agglutinating antibodies to Yersinia enterocolitica, Brucella abortus, Francisella tularensis and Salmonella urbana*.

Antisera to whole acetone-killed cells (WC) of B.a. and Y.e. were produced as described in previous studies (Hurvell 1972). Four rabbits were immunized with each strain and their antisera were pooled.

Antisera to the LPS from B.a. and Y.e. were produced as follows. From each LPS fraction $12.5 \mu \mathrm{g}$ were dissolved in $1 \mathrm{ml}$ of $0.15 \mathrm{M}-\mathrm{NaCl}$ and injected intravenously. Four rabbits were immunized per fraction. Ten days later a booster dose of $12.5 \mu \mathrm{g}$ was administered. Ten days after the booster injection the rabbits were bled. Sera from each group of rabbits were pooled. Sheep antiserum against rabbit IgM (kindly supplied by Sven-Eric Svehag, Department of Immunology, National Bacteriological Laboratory, Stockholm, Sweden) and swine antiserum

* Serological cross-reactions have recently been found between Yersinia enterocolitica type IX and Salmonellas containing O-antigen 30 (Hurvell 1973; unpublished data). 
against rabbit IgG (Dakopatts A/S, Copenhagen, Denmark) were used in the immunodiffusion tests against the gel-filtered $19 \mathrm{~S}$ and $7 \mathrm{~S}$ fractions.

\section{Gel filtration}

The antisera were treated with colloidal silicic acid (Aerosil/380, Degussa, Frankfurt/Main, West Germany) in order to remove $\alpha_{1}-, \alpha_{2}-$ and $\beta$-lipoproteins (Stephan \& Róka 1968) before gel filtration.

Two upward flowing columns $(2.5 \times 45 \mathrm{~cm})$ of Sephadex G-200 (Pharmacia Fine Chemicals AB, Uppsala, Sweden) in series and equilibrated with $0.1 \mathrm{M}$ tris-HCl buffer, $\mathrm{pH} 8.0$ were used. An amount of $5 \mathrm{ml}$ of undiluted pooled antisera was run through the columns. A peristaltic pump (Stålprodukter, Uppsala, Sweden) maintained a constant flow of $18 \mathrm{ml} / \mathrm{hr}$. The transmission of the eluate was recorded continuously at $280 \mathrm{~nm}$ by means of an 8300 Uvicord II ultraviolet absorptiometer (LKB-produkter AB, Stockholm, Sweden) using an $0.3 \mathrm{~cm}$ flow cell. The column effluent was collected in fractions (2-3 ml) using a time-controlled automatic fraction collector (Stålprodukter, Uppsala, Sweden). Every three consecutive fractions were pooled.

Fractions representing the middle of the leading side, the top, and the middle of the back side of $19 \mathrm{~S}$ and $7 \mathrm{~S}$ peaks were tested by immunodiffusion against the specific antisera to rabbit IgM and rabbit IgG and by analytical ultracentrifugation* (Spinco Model-E ultracentrifuge with photo-electric u.v.-scanning absorption system).

\section{Reduction and alkylation of immunoglobulins}

The procedures were performed as described by Frank \& Humphrey (1968) with some modifications.

The antisera (diluted to $10 \%$ in $0.1 \mathrm{M}$ tris- $\mathrm{HCl}$ buffer with $\mathrm{pH}$ 8.0) and the consecutive pooled fractions representing $19 \mathrm{~S}$ and $7 \mathrm{~S}$ from the Sephadex filtration were exposed to a final concentration of $0.03 \mathrm{M}$ dithiothreitol (DTT) (Cleland's Reagent, P-L Biochemicals, Inc., Milwaukee, USA). The mixtures were agitated and incubated at $30^{\circ} \mathrm{C}$ for $1 \mathrm{hr}$. Iodoacetamide (IOD) (Sigma Chemical Co., St Louis, Missouri, USA) was added to a final concentration of $0.008 \mathrm{M}$ and the mixtures were kept at $0^{\circ} \mathrm{C}$ for $1 \mathrm{hr}$. Each antiserum and each consecutive pool from the gel filtrations were tested for agglutinating antibody activity before and after the treatment with DTT and IOD. Controls showed that DTT and IOD did not affect the antibody-binding capacity of the agglutinating antigens under the conditions used.

\section{Agglutination test}

Preparation of the agglutinating antigens and performance of the tests have been described previously (Hurvell et al. 1971). The anti-

* The author wishes to thank Dr. H. Pertoft, Institute of Medical Chemistry, University of Uppsala, Sweden, for the analytical ultracentrifugations and sedimentation velocity analyses. 
sera and the pooled fractions from the gel filtrations were diluted with $0.15 \mathrm{M}-\mathrm{NaCl}$ in two-fold serial dilutions. Titres were recorded as the reciprocal of the highest final dilution of sera or fractions that showed definite macroscopic clumping, when viewed with a strong light against a dark background. Each specimen was assayed at least three times in duplicate to minimize the effects of errors in the tube dilution procedure. The variations in titres were within one dilution step.

\section{Absorption procedure}

Two $\mathrm{ml}$ from the fractions representing the top of each peak of $19 \mathrm{~S}$ and $7 \mathrm{~S}$ from the Sephadex filtered antisera were mixed with the sediment from $80 \mathrm{ml}$ of the respective agglutinating antigens, with the absorbance value of 0.3 at $540 \mathrm{~nm}$ using a $10 \mathrm{~mm}$ measuring cuvette (Beckman-B-Spectro-photometer). Each mixture was incubated at $37^{\circ} \mathrm{C}$ under continuous stirring for $2 \mathrm{hrs}$. and was then stored at $5^{\circ} \mathrm{C}$ for $18 \mathrm{hrs}$. The sediments were removed by centrifugation at $4000 \times \mathrm{g}$ for $1 \mathrm{hr}$. The supernatant fluids were tested for antibody activity by the agglutination test.

To control the specificity of the absorption tests some fractions were also absorbed with heat-killed bacteria of Escherichia coli (06) and Salmonella typhi-murium.

\section{RESULTS}

\section{Separation of $19 S$ and $7 S$ antibodies}

The results from the gel filtrations with Sephadex G-200 of the respective antisera are shown in Fig. 1. The first and second peaks may be considered to contain $19 \mathrm{~S}$ and $7 \mathrm{~S}$ antibodies, respectively, based on the criteria of the peak location. In the immunodiffusion tests the $19 \mathrm{~S}$ preparations gave no visible precipitation lines against anti-IgG and in the $7 \mathrm{~S}$ preparations no visible lines against anti-IgM were found. At the analytical ultracentrifugation, the $19 \mathrm{~S}$ and $7 \mathrm{~S}$ fractions from the gel filtrations gave homogeneous peaks with the sedimentation coefficients of $19 \mathrm{~S}$ and $7 \mathrm{~S}$ respectively.

\section{Agglutination test}

The sera prepared by immunization with WC and LPS from B.a. and Y.e. gave high agglutination titres both with homologous and with heterologous antigens (Table 1). 

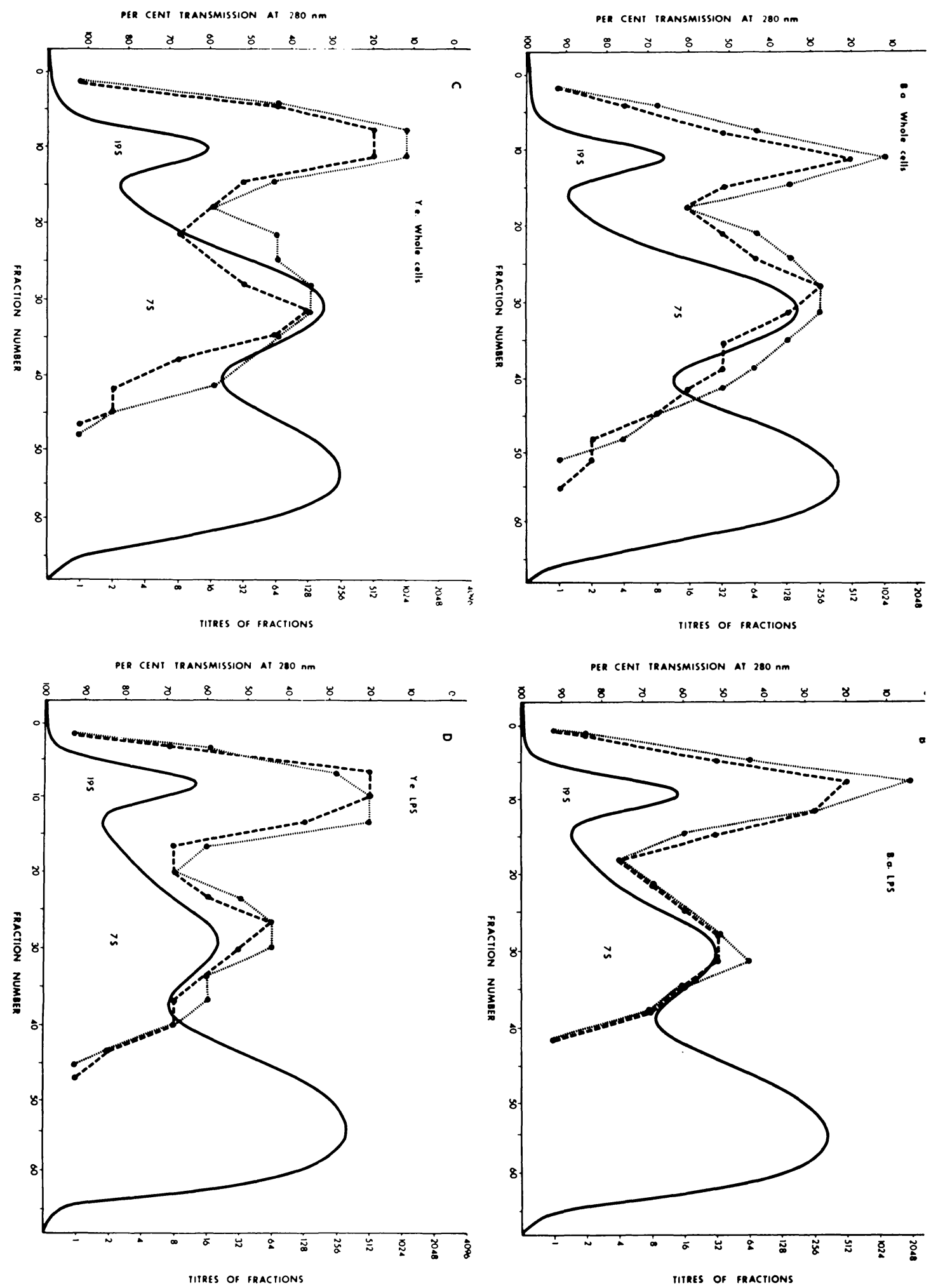

Figure 1. 
T a b l e 1. Homologous and heterologous agglutination titres of rabbit antisera to whole cells and lipopolysaccharides (LPS) of B. abortus (B.a.) and Y. enterocolitica type IX (Y.e.).

\begin{tabular}{lcc}
\hline & \multicolumn{2}{c}{ Agglutinin titres } \\
\cline { 2 - 3 } Antiserum & $\begin{array}{c}\text { B.a. } \\
\text { antigen }\end{array}$ & $\begin{array}{c}\text { Y.e. } \\
\text { antigen }\end{array}$ \\
\hline B.a. whole cells & 2560 & 2560 \\
B.a. LPS & 2560 & 1280 \\
Y.e. whole cells & 640 & 2560 \\
Y.e. LPS & 320 & 2560 \\
\hline
\end{tabular}

The agglutinating titres of the fractionated antibodies in the $19 \mathrm{~S}$ and $7 \mathrm{~S}$ peaks will be seen in Fig. 1. All the immune sera had cross-reacting agglutinins both in the $19 \mathrm{~S}$ and in the $7 \mathrm{~S}$ fractions. The homologous and heterologous agglutination titres for the top fractions within the $19 \mathrm{~S}$ and $7 \mathrm{~S}$ peaks of each antiserum showed relatively small titre differences. The differences between homologous and heterologous titre within the respective peak did not exceed two titre steps for any of the four immune sera. When, on the other hand, the highest titre levels - the homologous as well as the heterologous - for the $19 \mathrm{~S}$ fractions were compared with those for the $7 \mathrm{~S}$ fractions, the titres for the $19 \mathrm{~S}$ fractions were for all the immune sera higher than the corresponding titres for $7 \mathrm{~S}$. The differences varied between one and five titre steps. The greatest difference was noted for the serum against LPS from B.a., as will be seen from Fig. 1 (B). For the $19 \mathrm{~S}$ peak, the highest titre against homologous B.a. antigen was here $1: 2048$ and the corresponding titre for the $7 \mathrm{~S}$ peak was 1:64, which means a difference of five titre steps. The smallest difference between the highest titre levels was noted for

Figure 1. Homologous and heterologous agglutination titres in the gel-filtered (Sephadex G-200) fractions of rabbit antisera to whole cells and lipopolysaccharides (LPS) of B. abortus (B.a.) and Y. enterocolitica type IX (Y.e.). Each point corresponds to every three consecutive pooled fractions.

$$
\begin{aligned}
\cdots \cdots \cdots \cdots \cdots & =\text { homologous titre } \\
-\cdots- & =\text { heterologous titre. } \\
& =\text { optical density at } 280 \mathrm{~nm}
\end{aligned}
$$



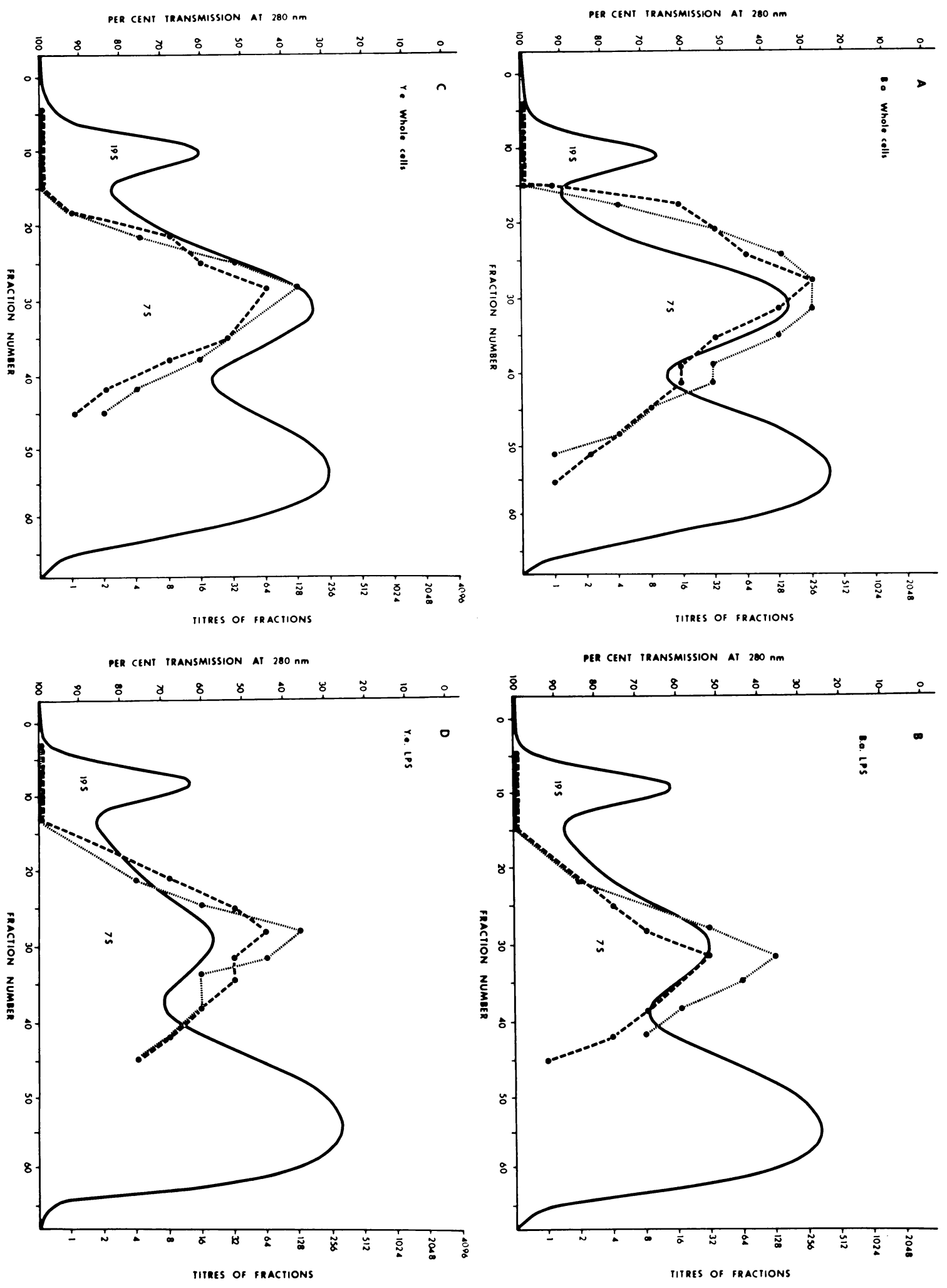

Figure 2. 
the immune serum against WC of B.a. It will be seen from Fig. 1 (A) that the heterologous titre for $19 \mathrm{~S}$ is $1: 512$ and for $7 \mathrm{~S}$ $1: 256$.

\section{Sensitivity of the agglutinins to DTT treatment}

The results are set out in Table 2. A marked decrease of the titres occurred for antisera against B.a. and Y.e. produced by the immunizations with LPS. For antisera against LPS from B.a. the homologous titre fell from $1: 2560$ to less than 1:10 and the

T a ble 2. Effect of dithiothreitol (DTT) and iodoacetamide (IOD) on homologous and heterologous agglutination titres of rabbit antisera to whole cells and lipopolysaccharides (LPS) of B. abortus (B.a.) and Y. enterocolitica type IX (Y.e.).

\begin{tabular}{|c|c|c|c|c|}
\hline \multirow{3}{*}{ Antiserum } & \multicolumn{4}{|c|}{ Agglutinin titres } \\
\hline & \multicolumn{2}{|c|}{$\begin{array}{l}\text { before DTT and IOD } \\
\text { treatment }\end{array}$} & \multicolumn{2}{|c|}{$\begin{array}{l}\text { after DTT and IOD } \\
\text { treatment }\end{array}$} \\
\hline & $\begin{array}{c}\text { B.a. } \\
\text { antigen }\end{array}$ & $\begin{array}{c}\text { Y.e. } \\
\text { antigen }\end{array}$ & $\begin{array}{c}\text { B.a. } \\
\text { antigen }\end{array}$ & $\begin{array}{c}\text { Y.e. } \\
\text { antigen }\end{array}$ \\
\hline B.a. whole cells & 2560 & 2560 & 320 & 320 \\
\hline B.a. LPS & 2560 & 1280 & $<10$ & $<10$ \\
\hline Y.e. whole cells & 640 & 2560 & 80 & 160 \\
\hline Y.e. LPS & 320 & 2560 & $<10$ & $<10$ \\
\hline
\end{tabular}

heterologous titre fell from $1: 1280$ to less than 1:10. For Y.e. the comparable titre decreases were from $1: 2560$ to less than $1: 10$ and from $1: 320$ to less than $1: 10$ respectively. For the antisera prepared by immunization with WC, a marked titre decrease also occurred after the DTT treatment. Both the homologous and the heterologous agglutination titre for B.a. antisera decreased

Figure 2. Homologous and heterologous agglutination titres in the gel-filtered (Sephadex G-200) fractions after treatment with dithiothreitol (DTT) and iodoacetamide (IOD).

$\begin{aligned} \cdots \cdots \cdots \cdots . . & =\text { homologous titre. } \\ ---- & =\text { heterologous titre. } \\ & =\text { optical density at } 280 \mathrm{~nm} .\end{aligned}$ 
by three titre steps. The corresponding decreases for antisera against Y.e. WC were by four and three titre steps, respectively.

The effects of DTT on the agglutinating capacity of $19 \mathrm{~S}$ and $7 \mathrm{~S}$ antibodies from the gel filtrations will be seen in Fig. 2. For all the antisera, the antibodies under the $19 \mathrm{~S}$ peak were sensitive to the DTT treatment. No agglutinating capacity was noted within the $19 \mathrm{~S}$ peaks after the reduction and alkylation of the immunoglobulins. The antibodies below the second peak, that is the $7 \mathrm{~S}$ antibodies, were seemingly resistant to the DTT treatment. No decreases of agglutination titres attributable to DTT could be demonstrated here. The agglutination titres for the particular fractions before treatment with DTT and IOD will be seen from Fig. 1.

\section{Crosswise absorption of $19 S$ and $7 S$ fractions}

The homologous and heterologous agglutination titres before and after the crosswise absorptions are presented in Fig. 3.

The agglutination titres were markedly reduced for all the fractions after the absorptions made with B.a. and Y.e. respectively. The titre decreases were noted both for the homologous and for the heterologous titres. The obtained results show that the agglutination titres for the fractions produced by the immunizations with B.a., both WC and LPS, tended to fall more markedly after the absorption procedure than did the analogous titres for fractions from corresponding immunizations with Y.e. This held true both for the $19 \mathrm{~S}$ and for the $7 \mathrm{~S}$ fractions.

A comparison of the effect of absorptions with respect to the agglutination-titre decreases for the $19 \mathrm{~S}$ and for the $7 \mathrm{~S}$ fractions from one and the same serum showed that the greatest decrease occurred for the $19 \mathrm{~S}$ fractions. This held true for both the homologous and the heterologous titres and was most noticeable for those fractions that derived from the immunizations with LPS from B.a. as well as from Y.e.

The absorption procedures performed with heat-killed E. coli and S. typhi-murium had no influence on the titres against B.a. and Y.e. of the respective fractions. 

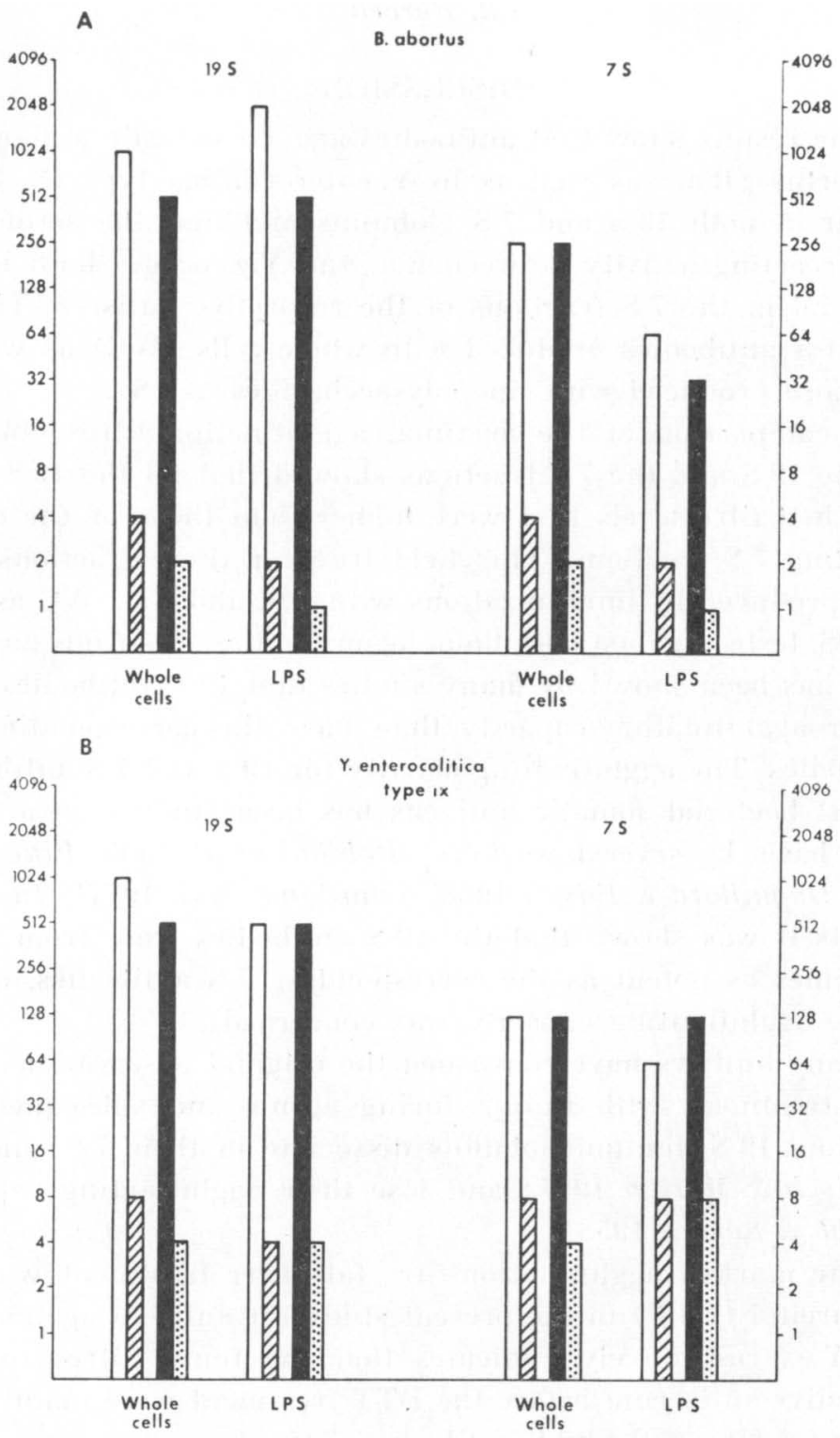

F igu re 3. Effect of absorptions on homologous and heterologous agglutinin titres of $19 \mathrm{~S}$ and $7 \mathrm{~S}$ fractions from rabbit antisera to whole cells and to lipopolysaccharides (LPS) of B. abortus (A) and Y. enterocolitica type IX (B).

Fractions in A are absorbed by heat-killed bacteria of Y. enterocolitica type IX.

Fractions in $B$ are absorbed by heat-killed bacteria of $B$. abortus.

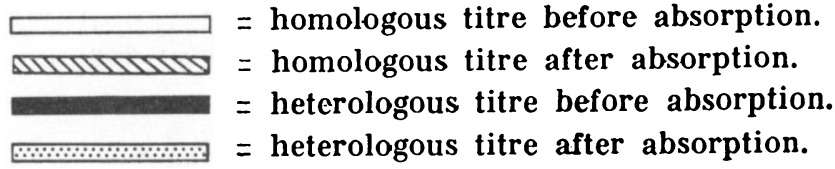




\section{DISCUSSION}

The results show that antibodies against somatic antigens in B. abortus (B.a.) as well as in Y.enterocolitica type IX (Y.e.) appear in both $19 \mathrm{~S}$ and $7 \mathrm{~S}$ globulins and that the serological cross-reacting activity between B.a. and Y.e. occurs both in the $19 \mathrm{~S}$ and in the $7 \mathrm{~S}$ fractions of the respective antisera. This is valid for antibodies produced with whole cells (WC) as well as for those produced with lipopolysaccharides (LPS).

A comparison of the maximal agglutination titres obtained for the $19 \mathrm{~S}$ and the $7 \mathrm{~S}$ fractions showed that all the $19 \mathrm{~S}$ fractions had titre levels that were higher than those of the corresponding $7 \mathrm{~S}$ fractions. This held true for those fractions that were produced by immunizations with B.a. and Y.e., WC as well as LPS, tested against both homologous and heterologous antigen.

It has been shown by many studies that $19 \mathrm{~S}$ antibodies have higher agglutinating capacity than have the corresponding $7 \mathrm{~S}$ antibodies. The agglutinating activity for $19 \mathrm{~S}$ and $7 \mathrm{~S}$ antibodies against bacterial somatic antigens has been studied on a molecular basis by several workers (Robbins et al. 1965, Pike et al. 1966, Daguillard \& Edsall 1968, Schulkind et al. 1971). In these reports it was shown that the $19 \mathrm{~S}$ antibodies were from 22 to 300 times as potent as the corresponding $7 \mathrm{~S}$ antibodies, as far as the agglutinating capacity was concerned.

Many authors have confirmed the original observations that, after treatment with thiol-reducing agents and subsequent alkylation, $19 \mathrm{~S}$ immunoglobulins dissociate in their $7 \mathrm{~S}$ subunits (Deutsch \& Morton 1957) and lose their agglutinating capacity (Grubb \& Swahn 1958).

The marked agglutination-titre fall after treatment with dithiothreitol (DTT) in the present study for antisera against B.a. and Y.e., respectively, indicates that the found titres for the respective antiserum before the DTT treatment were mainly due to the activity of the $19 \mathrm{~S}$ antibodies. The absence of measurable agglutinating activity in the $19 \mathrm{~S}$ peaks after DTT treatment also indicates that the specifically antibody-active macro-immunoglobulins obtained in the $19 \mathrm{~S}$ peaks did not contain any admixture, measurable by the agglutination reaction, of DTTresistant $7 \mathrm{~S}$ immunoglobulins.

The results of the absorptions of $19 \mathrm{~S}$ and of $7 \mathrm{~S}$ antibody fractions showed that, on comparison by pairs within the respective species, both the homologous and the heterologous aggluti- 
nation titres fell proportionally by more titre steps for the $19 \mathrm{~S}$ than for the corresponding $7 \mathrm{~S}$ antibodies. These differences between $19 \mathrm{~S}$ and $7 \mathrm{~S}$ antibodies were most marked for the fractions that derived from antisera against LPS, both from B.a. and from Y.e. These results might indicate that the respective $19 \mathrm{~S}$ antibodies have a greater tendency towards being absorbed to the cross-reacting antigenic determinants than have the corresponding $7 \mathrm{~S}$ antibodies.

No definite explanation can be given of this difference between $19 \mathrm{~S}$ and $7 \mathrm{~S}$ antibodies, but some possibility may be discussed. A cause might be found in the antigenic determinants for B.a. and Y.e. Results in a previous study (Hurvell \& Lindberg 1973 ) indicate that the cross-reacting antigenic determinants would be present in $\mathrm{O}$-specific polysaccharide side chains in the respective bacteria. The steric arrangement and the distance between the receptor sites on these chains may be thought to influence the ease with which contact can be established between the respective antibodies and antigens. Possibly, the greater number of combining sites in the $19 \mathrm{~S}$ immunoglobulins compared with the $7 \mathrm{~S}$ immunoglobulins may be a factor concerned in this partiality.

Previous absorption experiments with whole serum from antisera against whole cells of different Brucella species and Y.e. (Hurvell et al. 1971) showed, that a greater reduction of the homologous agglutinin titres was obtained, when antisera against Brucella were absorbed with Y.e. bacteria than when antiserum against Y.e. was absorbed with Brucella bacteria. This difference was confirmed in the present study. When both $19 \mathrm{~S}$ and $7 \mathrm{~S}$ antibodies in fractions derived from antisera against WC and LPS of B.a. were compared with corresponding antibodies from Y.e. antisera, the results obtained showed that after the heterologous absorptions of the antibody fractions the greatest reduction of the agglutination titres was obtained for the B.a. antibodies. These differences could indicate greater congruity between antibodies, both $19 \mathrm{~S}$ and $7 \mathrm{~S}$, against B.a. and antigen from Y.e. than between corresponding antibodies against Y.e. and B.a. antigen.

No definite explanations can be given of these demonstrated differences between B.a. and Y.e. There may be dissimilarities both in the respective antibodies and in the respective antigenic determinants. 
As regards the first alternative, differences may exist in, for instance, the avidity of the antibodies. Attempts are in progress to determine whether there may be any differences in the avidity of the antibodies to B.a. and Y.e.

In the second alternative, that is, dissimilarities in the respective antigenic determinants, there may be several causes depending upon the structure of the $\mathbf{O}$-antigen factors that are responsible for the cross-reactions in B.a. and Y.e. respectively. Differences may exist in the total structure of the respective polysaccharide molecules, but also in just a few terminal and antigendetermining monosaccharides. Structure analyses of the $\mathbf{O}$-antigenic side chains are in progress and will, possibly, provide answers to some of these complex questions.

\section{REFERENCES}

Ahvonen, $P$., E. Jansson \& $K$. Aho: Marked cross-agglutination between Brucellae and a subtype of Yersinia enterocolitica. Acta path. microbiol. scand. $1969,75,291-295$.

Akkermans, J. P. W. M. \& W. K. W. Hill: Yersinia enterocolitica serotype 9-infectie als storend element bij de serologische diagnostiek van brucella-infecties bij het varken. (Yersinia enterocolitica serotype 9-infections as a disturbing factor in serological demonstration of brucella-infection in swine). T. Diergeneesk. 1971, 24, 1654-1662.

Corbel, M.J.\& G. A. Cullen: Differentiation of the serological response to Yersinia enterocolitica and Brucella abortus in cattle. J. Hyg. (Lond.) 197.0, 68, 519_530.

Daguillard, F. \& G. Edsall: The agglutinating and bactericidal activity of IgM and IgG antibodies to the 9 and 12 factors of Salmonella typhi 0 901. J. Immunol. 1968, 100, 1112-1120.

Deutsch, H. F. \& J. I. Morton: Dissociation of human serum macroglobulin. Science $1957,13,600-601$.

Diaz, R., R. Lacalle, M. P. Medrano \& D. Leong: Immunobiological activities of the endotoxin from Yersinia enterocolitica strain M.Y. 79. Proc. Vth Int. Congr. Infect. Diseases, Vienna 1970, Vol. 2, Bacteria I, 11-17.

Frank, M. M.\&J.H. Humphrey: The subunits in rabbit anti-Forssman IgM antibody. J. exp. Med. 1968, 127, 967-982.

Fribourg-Blanc, A.: Etude par immunofluorescence des antigènes somatiques de Yersinia enterocolitica. (Study of the somatic antigenic structure of Yersinia enterocolitica by immunofluorescence). Ann. Biol. clin. 1971, 29, 263-270.

Grubb, R. \& B. Swahn: Destruction of some agglutinins but not of others by two sulfhydryl compounds. Acta path. microbiol. scand. 1958, 43, 305-309. 
Hurvell, B.: Serological cross-reactions between different Brucella species and Yersinia enterocolitica. Immunodiffusion and immunoelectrophoresis. Acta vet. scand. 1972, 13, 472-483.

Hurvell, B.: Serological cross-reactions between different Brucella species and Yersinia enterocolitica. Biological and chemical investigations of lipopolysaccharides from Brucella abortus and Yersinia enterocolitica type IX. Acta path. microbiol. scand. Sect. B. 1973, 81, 105-112.

Hurvell, B. \& A. A. Lindberg: Serological cross-reactions between different Brucella species and Yersinia enterocolitica. Immunochemical studies on phenol-water extracted lipopolysaccharides from Brucella abortus and Yersinia enterocolitica type IX. Acta path. microbiol. scand. Sect. B. 1973, 81, 113-119.

Hurvell, B., P. Ahvonen \& E. Thal: Serological cross-reactions between different Brucella species and Yersinia enterocolitica. Proc. 11th Nord. Vet. Congr., Bergen 1970, 282.

Hurvell, B., P. Ahvonen \& E. Thal: Serological cross-reactions between different Brucella species and Yersinia enterocolitica. Agglutination and complement fixation. Acta vet. scand. 1971, 12, $86-94$.

Pike, R. M., M. L. Schulze \& C. H. Chandler: Agglutinating and precipitating capacity of rabbit anti-salmonella typhosa $\gamma \mathrm{G}$ and $\gamma \mathrm{M}$ antibodies during prolonged immunization. J. Bact. 1966, $92,880-886$.

Robbins, J. B., K. Kenny \& E. Suter: The isolation and biological activities of rabbit $\gamma \mathrm{M}$ - and $\gamma \mathrm{G}$ anti-salmonella typhimurium antibodies. J. exp. Med. 1965, 122, 385-402.

Schulkind, M. L., M. Herzberg \& J. B. Robbins: Specific secondary biological properties of purified rabbit immunoglobulin $M$ and immunoglobulin $\mathbf{G}$ antibodies to Brucella abortus and Bordetella pertussis. Infect. Immun. 1971, 4, 220-227.

Stephan, W. \& L. Róka: Adsorption von Lipoproteiden. (Adsorption of lipoproteins). Z. klin. Chem. klin. Biochem. 1968, 61, 186190.

Szita, J., M. Káli \& B. Rèdey: Serological diagnosis of Yersinia enterocolitica. Acta microbiol. Acad. Sci. hung. 1971, 18, 113-118.

Wauters, G., L. LeMinor \& A. M. Chalon: Antigènes somatiques et flagellaires des Yersinia enterocolitica. (Somatic and flagellar antigens of Yersinia enterocolitica). Ann. Inst. Pasteur 1971, $120,631-642$.

\section{SAMMANFATTNING}

Serologiska korsreaktioner mellan olika Brucella species och Yersinia enterocolitica. Agglutinationsaktivitet hos $19 \mathrm{~S}$ och $7 \mathrm{~S}$ antikroppar mot somatiska antigener hos Brucella abortus och Yersinia enterocolitica typ IX.

Antisera från kaniner immuniserade med dels acetonavdödade helceller och dels med lipopolysackarider från Brucella abortus (B.a.) 
och Yersinia enterocolitica typ IX (Y.e.) gelfiltrerades på Sephadex G-200 kolonner.

Samtliga antisera hade serologiskt korsreagerande agglutininer mot B.a. och Y.e. i både $19 \mathrm{~S}$ och $7 \mathrm{~S}$ antikroppsfraktionerna.

Den homologa och heterologa agglutinationsaktiviteten hos respektive $19 \mathrm{~S}$ och $7 \mathrm{~S}$ antikroppar testades före och efter behandling med dithiothreitol (DTT) och efterföljande alkylering. $7 \mathrm{~S}$ antikropparna var i motsats till $19 \mathrm{~S}$ antikropparna resistenta mot DTT-reduceringen.

Resultaten från gjorda heterologa absorptioner av respektive $19 \mathrm{~S}$ och $7 \mathrm{~S}$ antikroppsfraktioner tyder på att $19 \mathrm{~S}$ antikroppar mot såväl B.a. som Y.e. hade större benägenhet att absorberas till de korsreagerande antigena determinanterna än vad motsvarande $7 \mathrm{~S}$ antikroppar hade. Agglutinationstitrarna för såväl $19 \mathrm{~S}$ som $7 \mathrm{~S}$ antikroppsfraktioner härrörande från immuniseringarna med B.a. (både helceller och LPS) sjönk kraftigare efter heterologa absorptioner än vad de analoga titrarna för motsvarande Y.e.-antikroppsfraktioner gjorde efter heterologa absorptioner. Möjliga förklaringar till dessa differenser diskutterades.

(Received February 24, 1973).

Reprints may be requested from: Bengt Hurvell, Department of Bacteriology, National Veterinary Institute, S-10405 Stockholm 50, Sweden. 